DOI: $10.22559 /$ folklor.840

folklor/edebiyat, cilt:25, sayı:98, 2019/2

\title{
Yaşar Kemal'in Romanlarının Sosyolojisinde İnsan Sevgisi ve Değerinin Varoluşsal Kaynakları
}

\author{
Existential Sources of the Love of Humanity and Human \\ Value in the Sociology of Yasar Kemal's Novels
}

Aziz Şeker ${ }^{1}$

\begin{abstract}
$\ddot{O} z$
Yaşar Kemal romanlarında, insan, toplum ve çevre üzerine birçok konuyu işlerken, kendi düşünsel tutumuna uygun hareket eden kadın ve erkek roman karakterlerini de başarıyla kurgulamıştır. Yaşar Kemal bir aydın olarak adalet, barış, eşitlik, özgürlük, demokrasi ve insan hakları söylemine sahip olduğu kadar, romanlarında oluşturduğu karakterler aracılığıyla da bu olgularla ilgili tartışmaların yapılmasına olanak sağlamaktadır. Bu açıdan roman evrenine indiğimizde, roman karakterlerinin düşünce dünyaları ile insana, topluma ve çevreye bakış açılarının insan sevgisi, değeri ve hoşgörü üzerine biçimlendiğini görürüz. Yaşar Kemal'in romanlarında insan en yüksek değerdir. Elbette bunun tam da karşısında kötü olanın sergilendiği, kritik edildiği bir roman evrenini başarıyla çizdiğinden söz etmek mümkündür.

$\mathrm{Bu}$ çalışmada felsefi anlamda iyi ve kötünün karşı karşıya geldiği Yaşar Kemal'in romanlarının sosyolojisinde, insan sevgisi ve değerinin dayandığı varoluşsal kaynaklar irdelenirken, romanının demokratik işlevine ilişkin bir öngörü oluşturulmaya çalışılmıştır.
\end{abstract}

Anahtar sözcükler: Yaşar Kemal, insan sevgisi, insan değeri, roman sosyolojisi

1 Dr. Amasya Üniversitesi. shuaziz@gmail.com 


\begin{abstract}
While working on many subjects on human, society and environment, Yasar Kemal also successfully built the female and male novel characters who act in accordance with his intellectual attitude. Yasar Kemal was an intellectual that reflected in his works a discourse of justice, peace, equality, freedom, democracy and human rights and through his characters, he opened a path for a discussion about these phenomena. When we consider this aspect of the novel universe, novel characters' worlds of thought and their viewpoints of people, society and environment are built on love for human, human value and tolerance concepts. Human is the highest value in Yasar Kemal's novels. It is also possible to say that Yasar Kemal also successfully created a novel universe in which the evil is exhibited and critically criticized.

While examining the existential resources on which the love for humanity and human value are based in the sociology of Yasar Kemal's novels, in which philosophically good and evil are juxtaposed, this study also aims to create an insight for the democratic function of his novels.
\end{abstract}

Keywords: Yasar Kemal, love, the love of humanity, human value, novel sociology

\title{
Giriş
}

Bir sanat eserini anlamak kendi içinde sanat işi olan, sanatçının tasarımını yeniden ele geçirmektir. Herhangi bir insan eylemini yorumlamak ise eylemcinin güdüler ve niyetler ağını yeniden yaratmaktır. Her iki durum da, her şeyden önce, yakınlığı paylaşılan deneyime dönüştürmeyi, yani bir başka insanoğlu ile bir tür sempatik özdeşleşmeyi gerektirmektedir (Bauman, 2017a, s. 16). Bu yaklaşımla ele alındığında, Modern Türk romanının önemli yapı taşlarından biri kabul edilen Yaşar Kemal'in, insan onuruna ve haysiyetine verdiği değerle romanını geliştirirken, aydın tutumuyla da demokrasiyi yakından ilgilendiren konuların tartışılmasında etkili olduğunu görürüz. Yine insan sevgisi ve özgürleşmesi yönüyle yapıtları, okurlar açısından da bu değerlerin paylaşıldığı bir deneyim alanı açar. Sanatının amacıyla sevgi, özgürlük, umut ve adalet ögeleri bir insan felsefesi tartışması sunar.

Yaşar Kemal romanlarında, toplumda yaşamış insanlara değinir. Onların hayatlarını işlerken, okuyucuyu kendi tasarımına davet eder. Umut eden, korkunun üzerine giden, sevgi dolu roman karakterleriyle okuyucu arasında güçlü bir bağ kurarak, varoluşsal sorgulamalarına olanak tanır. Okuyucuyu insanı ve toplumu sarsan sorunlar karşısında hep bir tanıklığa çağırır. Çoğunlukla Çukurova toplumsal-tarihsel gerçekliğinin üzerinde bina edilmiş romanlarında bile tanıklarla dolu bir bellek sunar. Bunun yanında kendisi de tanıktır, ya da belki de kötü şeylere "tanıklık etmenin utancından kurtulmak için” iyi ve güzel şeyler için roman yazarken, bu tarihsel tanıklığını, insan varlığının bir ifadesi olarak edebiyata taşır (Nichanian, 2011, s. 63, Mengüşoğlu, 2017, s. 322). Başka bir deyişle dışlananın, güçsüzün, emeği sömürülenin, kültürü ve kimliği inkâr edilenin yanında durur. Yaşananları bir reel tarih ve toplum okuması olarak bir sosyal belge hâlinde insanlara sunar. Yaşar Kemal'in, olayların toplumsal ve tarihsel boyutlarını, roman karakterlerinin varlık buldukları toplumsalı canlı bir biçimde yansıtma başarısıyla ilgili diyebiliriz ki, romanının, tıpkı on sekizinci yüzyılda İngilizcede ilk ortaya çıktığında bu türün sıra dışı yönünü niteleyen "gerçek dünyaya baştan çıkarıcı yakınlığı” ile 
bir akrabalığı vardır (Mackay, 2018, s. 14). Bu baştan çıkarıcılık, Yaşar Kemal'de varoluşsal bir kavganın yanında insancıl bir felsefi söylemi arkasına alarak, gerçek karakterler aracılığıla zengin bir roman dünyasına dönüşür. Örneğin Yaşar Kemal'in roman dünyasında, bu gerçek insanlar içinde insan öldüren tiplere yer verildiği kadar ölüme karşı duran, sevgiyle bütünleşmiş tipler de yer alır. Bunu ise genelde kan davası güden Çukurova ağalarını ileri sürerek anlatmayı tercih eder. Demirciler Çarşısı Cinayeti ve Yusuf̧̧uk Yusuf bu yönüyle sosyolojik bir içeriğe sahiptir. Bu romanlarında değişen toplum dinamiğinde, bireysel trajediler içinde sadizm öyle bir boyut kazanır ki, romanın erkek karakterleri Mustafa ve Derviş Bey’in davranışları okuyucuyu adeta ürpertir. Şunu demek isteriz, elbette kötülüğün ifade biçimleri arasında yer alan sadizm, bir yıkımı seyretmekten zevk almaktır ve yıkımların en acısıysa insanoğlunun ölümüdür. Sadizm, kötülüğün ta kendisidir: Maddi bir yarar sağlamak üzere öldürmenin hakiki bir kötülük sayılabilmesi için katilin, beklediği yararın ötesinde öldürme eyleminin kendisinden de haz duyması gerekir (Bataille, 2016, s. 16). Mustafa'nın annesi Karakız Hatun'un kan davasını sürdürürcesine Derviş Bey'in oğlunu gidip öldürmesinde, bu haz ve ürperti doruğa çıkarken, aşireti dağılmasın diye makineli tarıma geçilip topraktan iş gücü ihtiyacı düştüğü için aşiret üyelerinin başına geleceklerini düşündüğünde ise insani bir tepki verir aynı kişi ve bir tek insanın bile açlığa terkedilmesini kabul etmez. Ayrıca bu iki feodal beyin bazı özellikleri ise Türkmen geleneklerine bağlılık anlamında okuyucuda vicdani bir bakışı tartışmaya açar. Yaşar Kemal'in romanlarında, yaşadığı kültürel ve sosyal çevre içinde insan saygın bir varlıktır. Yazar insanı yargılamaz, bir çerçeveye hapsetmez. Eleştirilen bir insanın ölümünde bile yaktırdığı ağıtlarla onu saygın insanlar ailesine kabul ettirir. Ayrıca yazar, kendisini anımsatacak boyutlarda, gelişen roman karakteriyle bizleri tanıştırır. Onları başlangıçtan itibaren bir kaderle sınamaz. Kuşkusuz birisini bir şeyle tanımlamak..., kişiyi, kontrol etmesi şöyle dursun, etkileme imkânının bile bulunmadığı bir kadere tutsak etmek demektir ki bunu asla yapmaz (Kemal, 1998c, Bauman, 2017b, s. 42). Bu nedenle roman karakterleri yaşayan bir akışkanlığa sahiptirler. Yazar bir üst anlatıcı olarak romana girdiği yerlerde insan değeri ve sevgisi üzerine düşüncelerini açıkladığı gibi yarattığı kadın ya da erkek hatta çocuk roman karakterleri yolu ile de insani ölçekte varoluşsal bir tartışmayı okuyucuya taşımaktan geri durmaz. Buradaki temel varsayımımız yani Yaşar Kemal'in en köklü itirazlarından biri, insanın aşağılanmasınadır (Sadak, 2017, s. 67). Örneğin oluşturduğu roman karakterlerinden İnce Memed gibi Yaşar Kemal de aşağılanmaya ve zulme karşı insanlık adına başkaldırmıştır ve bu nedenle Yaşar Kemal, sosyal ve siyasal aktivizmi yüzünden işkence görüp hapsedilmiştir. Yaşar Kemal'e göre insanlar doğanın parçasıdır, fakat ayrıca daha yüksek bir bilincin ve insani faaliyete olduğu kadar doğaya da önem veren insan imgelemi tarafından keşfedilen veya oluşturulan ruhani bir düzenin de parçasıdırlar. Yaşar Kemal, İnce Memed'in her cildinde destanı yeniden yazarken temelde kahramanın duygusal, entelektüel ve manevi olgunlaşmasıyla, sosyal adalet endişesiyle ve özellikle kişisel arzuları ile toplumun talepleri arasındaki çatışmayla ilgili orijinal hikâyenin belli unsurlarını vurgular (Tharaud, 2017, s. 57, 86, 355). Bu bağlamda Yaşar Kemal, kendi düşüncelerinin felsefi temelindeki değerler ekseninde biçimlendirdiği İnce Memed’te insanların ezilmemesi, dışlanmaması, adaletli paylaşım, sömürüye karşı durmak ve hakkını aramak anlamında derin bir insani mücadeleye dönüşür. Yine diğer bütün romanlarında ana roman karakterleri tarafından verilen mesajlarda da bu ve buna benzer insancil bir felsefe derinlik kazanır. 


\section{Yaşar Kemal'in romanlarında insan felsefesi ve roman karakterleri aracılığıyla in- san varoluşu üzerine yapılan tartışmalar}

Yaşar Kemal modern Türk romanında dünyayı, doğduğu coğrafyayı, insanı, toplumu, doğayı derinden anlayan, çözümleyen ve aktaran bir yazardır. Türk romanının tarihsel geçmişine ve birikimine, özgün roman sosyolojisiyle önemli katkılarda bulunmuştur. Onun roman anlayış1 insanc1l bir söylem üzerine yükselir; insan felsefesi ve değerleri açısından zengin bir sosyal/ kültürel yapıya dayalıdır. Bu özelliği, onun kült eseri İnce Memed başta olmak üzere hemen diğer bütün eserlerinde görmek mümkündür. İnce Memed, Türkiye'nin özellikle Çukurova's1nın bereketli topraklarında, tarımda kapitalistleşmenin başladığı dönemi içine alır. Eski ağalar, yeni beyler, topraktan pay kapmanın ve endüstriyel tarımdan gelecek zenginliğin farkında olan yerel bürokratlar ve siyasiler hırsla zenginleşmenin amansız mücadelesine girerken, giderek yoksullaşan köylünün; elindeki toprakları bile ağaların zulmüyle kaybedenlerin sığınacağı ve toplumsal belleğinde besleyeceği, olumlu değerler kazandırılmış bir destansı kurtarıcı arayışının öyküsü olarak anlam bulur. İnce Memed, ağalar ve sömürü etrafinda geçen ilk üç ciltte sosyal adalet mücadelesinin sonuçsuz kalacağına inanıp, güneyde bir kasabaya ikinci eşi Seyran ile yerleşmeye karar verse dahi, bu yerleşme uzun sürmez; son ciltte çeltik tarımının insan canı ve sömürüsü pahasına geldiği noktada yakın arkadaşını öldürten bir çeltik ağasını vurup, Toroslara doğru yola çıkmıştır. Aslında yazar, bir zorunluluk bilinciyle İnce'yi adalet arayan, ezilenin yanında yer alan bir sosyal eşkıya formunda dağlara gönderirken, okuyucuda sürmesini istediği adalet ve eşitlik olgusunun, insan sevgisinin, ezilenlerin her seferinde muhasebesini yapmasının ön koşullarını oluşturmaktadır. Romanın dış sosyal ve siyasal bağlamını oluşturan çok partili sürece geçişin kilit noktalarını görmemizi sağladığı gibi çevredeki ekonomik dönüşümün mantığını anlamaya sürükler okuyucuyu... Roman kahramanı İnce Memed yalnızca bir sosyal eşkıya değildir. Nehir roman boyunca felsefi bir temel inşa ederek kavgasını sürdürür. Bunun içinde bir başka insana duyduğu katıksız sevgiyi de yer yer okuruz. Örneğin romanın daha başlangıcında on birinde olan İnce Memed'in, annesi Döne'yle, Abdi Ağa'nın zulmüne karşı durarak tarlada çalışmaları, evlenmeye karar verdiğinde çocukluk arkadaşı Hatçe'ye duyduğu sevdasının filizlenir olması ilk çelişkiyi ortaya çıkarmıştır. Memed içine işleyen sevdayı psikolojik yansımalarıyla düşünür: "Belki umuttur. Belki de bir özlemdir. Özlem sicacıktır. Özlem bir dost, bir sevgilidir. Sarıverir insanı sıcaklı̆̆l...” (Kemal, 2000a, s. 85). Abdi'nin yeğenine verilecektir Hatçe. İnce alır kaçırır onu ve destan başlar. İlkin Kesme köyünden Süleyman’a sığınır. Dönüşü yok eşkıya olacaktır. Süleyman, “bütün çarelerini kendi yaratacaksın”, diyerek aslında bireyin gücüne ve biricikliğine verdiği önemi sergiler. Romanda ayrıca Çukurova'ya yerleştirilen Türkmenlerin yer yer bir ağıda dönen yakarışlarıyla karşılaşırız. Türkmenlerden, "Koca İsmail, aşiret lafi açıldı mı günlerce anlatır, yorulmazdl. Özgür bir dünyanın özlemini çekerdi." Diğer yandan Memed dağlardadır, "herkesin topră̆ herkesindir" söylemiyle mücadelesini sürdürmektedir (Kemal, 2000a, s. 128, 281, 297).

Pek bir rasyonel karşılığ 1 olmasa da merkezi otoriteden ve modernitenin nimetlerinden çok uzakta yaşayan topraksız yoksul köylüyü, toprak dağıtma meselesi İnce Memed'in haklı kavgasına çeker. Roman boyunca İnce Memed'in konuk olduğu kişilerin, insanlık konusunda tartışmaları, yazarın okuyucuya sundukları arasında felsefesi derinliği bulunan saptamalarla yer alır. Örneğin İnce Memed, Koca Osman ile eşi Kamer Ana’nın evine gizlendiğinde, Koca Osman’ın kendi eşine söylediklerinde insan olabilmenin sırrı sorgulanır: "Insan olmak... 
Insan olmak... Insan olmak," diyor, yürüyordu. "Insan olmak, Kamer Ana, insan olmak... Bak bir ayağım çukurda. En çok, en çok daha on yıl yaşarım. Sonra üfürüverirler, can kuşu kafesten uçar gider. Insan olmak Kamer Ana, insan olmak. Her işin başı bu. Korkudur insanı alçaltan, insanlıktan çıkaran. Bunu bilir, bunu söylerim.” Sonraki sayfalarda yazar, bu yaklaşımı İnce Memed'e de söyletir: "Bir insan ne kadar yürekliyse, o kadar korkaktır. Ya da bir insan ne kadar korkaksa o kadar yüreklidir. Bunun böyle olduğunu bir insan ancak seksenine gelince anlar." Yazar, İnce Memed çetesindeki imam eşkıya Ferhat Hocayla da, kendi düşünce dünyasını taşır: "Allah kulu kul yaratmış, kulu kimseye kul yaratmamış. Diretmeyen insan Allaha karşı insandır...” (Kemal, 2000b, s. 31, 65, 84). Kemal, kısaca korkunun üzerine giden, başkalarına kul olmayan insan kişiliğini yüceltir. Koca Osman ile konuştuklarında Ferhat Hoca, yazarın insana bakışını somutlaştırır: "Yılmış adam Allahın makbul kulu değildir," dedi. "Yılmış, korkmuş, ürkmüş insan kadar kötü bir mahluk halk etmemiştir yaradan. Dünyada cehennemden hiç çıkmayacak, ebedi yanacak bir yaratık, yılmış adamdır. Allahın en edna kulu korkmuş adamdır, korkmuş adam insanlı̆̆ın yüz karasıdır...” (Kemal, 2000b, s. 86, 87). Ali Safa Bey, Koca Osman'ın kaldığı köyü boşaltmaları için kurşunlatır, hayvanları öldürtür, köyün boşaldığını gören Ferhat Hoca önlerine geçerek, insanın hangi durumlarda haklı bir davanın öznesi olabileceğinin koşullarını anlatır: "Zulme karşı koymamak kafirliktir," diyordu. "Çocuğunun rızkını, baba yurdunu korumamak, bırakıp gurbet ellere düşmek kafirliktir. Zulme karşı koymamak zalime ortak olmaktır. Korkmak, korkudan dolayı yılmak kafirliktir." "Allah yoksulunu yalnız bırakmayacaktır,” diyor, büyük imanını sesinde topluyordu. "Allah zulme karşı koyanlarla her zaman birlik olmuştur. Yoksa yeryüzünde zulüm bu kadar azalır mıydı? (Kemal, 2000b, s. 170, 180). Umudun nasıl değerli bir nimet olduğu anımsatılır. Yaşamak için her şeye katlanan insanlarıyla... Yeri gelir bir değirmenciye söyletir, "Bir kişi bütün dünyayı sevincine katar da güldürür, ağıdına alır da ağlatır. Böyledir bu. Bir tuhaf yaratıktır şu insanoğlu.” Ümmet'e söyletir: “...dünya kurulduğundan bu yana insanoğlu insanoğlunu tartmıştır. İnsanoğlu, insanoğlunu bildiği kadar hiçbir şeyi bilmez." Yeri gelir Ferhat Hoca ile taşır bu tür düşüncelerini: “İnsanoğlu yiğit yaratıktır... İnsanoğlu mert, onurlu yaratıktır” (Kemal, 2000c, s. 177, 466, 540). İnsan onurunu önemser. Bununla ilintili bir ifadeyi Murtaza Ağa tarafından adam öldürmesi istenen Rüstem'le dile getirir: "Ben adam öldürmem. İsan öldürmek çok kötüdür. İnsan hiç Allahın yaptı̆̆ı en güzel binayı yıkar mı?" (Kemal, 2000d, s. 75, 441). Ferhat Hoca ve diğer eşkıyalar bir köyde toplandığında Alevi dedesi Dursun Dede ise sazıyla dillendirir: “...Insana ölüm yok. Insan muhabbete, insan sevgiye doğuyor. İnsan sevgiye doğmuyorsa insan olamazd, o zaman ölürdü işte... Insan insana doğuyor... Evreni sevgi yarattı, topră̆l, gökyüzünü sevgi yarattı, onun içindir ki evren böylesine sonsuz, toprak bu kadar zengin, yaratıcı, gökyüzü böylesine ışık kaynă̆ı. İnsanı sevgi yaratt, onun içindir ki insan bu kadar yaratıcl, böylesine güzel," diyordu Dursun Dede... Insan güzel olacak, diyordu Dursun Dede. Insan her gün biraz daha sevgi dolu, biraz daha mutlu, biraz daha zulme karşı, kötülüklere karşı bilenerek doğacak, çünkü onu sevgi yarattı (Kemal, 2000d, s. 138, 139). Bu sosyal eşkıyalar Dede Sultan'ın köyünde ne kadar muhtaç insan varsa onlara yardımcı olurlar. Bu, adeta insan olmanın zorluğu üzerine bir arayıştır... Sonra Abdülselam Hoca, Memed, Zeki Nejad, Müftü ile otururken konuşur: "Çok keramet var insanda," diye kendi kendisine konuşurcasına söylendi: "Çok keramet var atlarda, çok keramet var kuşlarda... Çok keramet var arıda..." Ak dişlerini ışılatarak güldü, utkulu bir 
insanın kendine güvenirliğiyle güldü: “Çok keramet var toprakta...” (Kemal, 2000d, s. 174). Cümle aralarında geçse bile "insan" odağında dile getirilen her düşünce daha çok bu dünyaya ait bir girişim olan insanın, toplumsal bir varlık olarak onuruyla kendisini ve çevresini inşa etmesiyle ilgilidir. Kemal, değișen insanı kaleme alır. Özgürleşerek kendi varlığını inşa eden insan değişimle gelir. Bu değişimin özünde sevgi vardır. Örneğin bir Akdeniz kasabasına yerleştiklerinde Seyran'daki değişim sevgiyle anlam bulur. Yazar bunu genel hatlarıyla Seyran'a ifade ettirir: “...Insan, hangi insan olursa olsun, yaşamı değişir, günü sevinç içinde başlar, sevinç içinde sürer giderse güzelleşir...” Ve Memed romanın finaline doğru insanın geleceğinin yine insanda olduğunun altını çizer: “...İnsan yaratığ şu evrendeki yaratıkların en korkaklarından birisidir, ama içlerinde çok da yüreklileri var, Hürü Ana, Ferhat Hoca gibi. Bu dünya o yürekli insanların yüzü suyu hürmetine ayakta duruyor...” (Kemal, 2000d, s. 238, 242).

Yaşar Kemal roman karakterlerinden yola çıkarak mesajlarını iletir. Onurlu, umutlu ve yürekli, korkunun üzerine, eşitsizliklere karşı gidebilen insan romanın var oluş kaynaklarının felsefesini imler. Kötüyle mücadele etmenin önemini her seferinde paylaşır. Ferhat Hoca'nın şu cümlelerinde rastladığımız gibi: "İnsan soyu başkaldırmayı yemek, içmek, yaşamak, uyumak, çocuk yapmak gibi bir yaşama biçimi yapmazsa bugünden de bin beter olacak, içi boşalacak, duymayl, düşünmeyi, sevmeyi, sevişmeyi, dostluğu, arkadaşlı̆̆l, göğ̈̈n, yerin, kurdun kuşun, akar suyun, tanyerindeki ışığın, yürekteki sıcaklığını unutacak... tekmil kötülüklere başkaldır, iyilik getir." Hak ve adalet temelinde sürekli konuşan bir imam eşkıyanın yanında Hürü'nün umudun ne kadar değerli bir besin olduğunu dile getirmesini de unutmamak gerekir: “...umudun ölmesi, insanın ölmesinden daha beterdir” (Kemal, 2000d, s. 331, 371).

Yaşar Kemal'in bir başka roman serisi "Dağın Öte Yüzü” üçlüsünde, kültürel koddaki insana bakışın birçok yönünü okuruz. Yazar köy sosyolojisi üzerine de romanda okuyucuya bir şeyler sunar. Örneğin köy kollektif bilincini örneklercesine, ileri sürdüğü şu tespit önemsenmelidir: "Köylü milleti bu! Bir kere bir şeye heyye demesin, aklı kesmesin. Korkma gerisinden. ” Ara ara tecrübeyle sabit atasözlerini kullanır “...deli bir dostun olacă̆ına, akıllı bin düşmanın olsun, daha yeğdir” (Kemal, 2000̆̆, s. 24, 299). İnsan ilişkilerindeki belirleyici düşünceleri roman sayfalarında detaylıca okuruz. Meryemce ile arası açık olan Koca Halil ötede beklerken yemek yiyen aileden Ali düşünür, "Bir yerde yemek yerken, düşman bile olsa, babayın kanlısı bile olsa yemeye buyur etmeden olmazdı” (Kemal, 2000̆̆: 331). Türkmen kültürünün konukseverliğini aslında yansıtır. Bu kültürde insana saygı ön plandadır. Köylü ile konuşmayan öfkeli Meryemce'nin şu cümleleri insana bakıştaki olgunluğu yansitır: "Sizi bağışladım. İnsanoğlu ne kadar kötü, ne kadar zalim de olsa bir iyi yanı var." Ardından, konuşmamak için yemin eden yaşlı kadın, etrafındaki çocuklara söylemek ister: "Insanoğlunun, belki de en güzel yeri çocukluğu. Büyüyesiniz, büyük büyük, uzun ömürlü olasını çocuklar. Benim ak güvercinim” (Kemal, 2000h, s. 91, 101).

Korku, çocuk gerçekliği ve ölüm romanın dinamiğine yön verir. Yazar, roman boyunca yoksul köylünün borçları içinde yaşarken kötü geçen kış günlerinde bir kurtarıcı rolü verdiği, ermiş olarak gördüğü Taşbaşoğlu'na işlev yükler: “korkmak yarl ölmektir.” "Çocuklar büyüklerin gizlediklerinin aynasıdır." "İnsanoğlu ışı̆̆ı sever. Bir lokma ışık için ölür.” İşte bu ışığın ifade ettiği anlamı farklı bir tartışmaya çekercesine yalnız kalan Koca Halil'e söyletir: “ölüm en büyük boşluktu” (Kemal, 2000h, s. 59, 108, 169). Taşbaş’’n isteği üzerine köylünün 
konuşmadığı kötü bir tip olan Muhtar Sefer bile insan ve yalnızlık üzerine söyleyecek bir şeylere sahiptir: “...Insanın bir yerde, bir işte tek başına kalışı ölümden de beterdi. İşte ölüm dedikleri de buydu. Sonsuz bir yalnızlıktı, çaresizlikti." Köylüye yapmadığını bırakmayan Sefer kendisiyle konuşurken: "İnsan hiçbir zaman hırsının, coşup gelen yüreğinin elinde oyuncak olmamalı. Her bir işi akıl terazisine vurmalı" dese bile Meryemce'nin öldürülmesinden sorumlu olacaktır. Köylü onunla konuşmamayı sürdürünce, "Sefer şimdi anllyordu. Küsmüş insanlardan daha korkuncu yoktu bu dünyada” (Kemal, 2000h, s. 226, 296, 305). Romanın karakterlerinden Taşbaş bir ermiş değildir. Ancak ermiş niteliğinde biri olsaydı yaşadığı köydeki insanlar için beklentilerini düşünmekten de geri durmaz: “...Hak, adalet üzere yürümelerini isterim. Çoğun aza eklenmesini isterim. Kimse kimseyi ezmesin, soymasin, hak yerini bulsun isterim” (Kemal, 2000h, s. 329). İşte hak ve adalete duyulan gereksinim ve onun için mücadele roman dinamiğinin felsefi temeli olur. Köydeki otoritesini sarstı̆̆ için Taşbaş’1 kasaba karakoluna şikâyet eden Muhtar Sefer, tutuklanmasına neden olur. Yazar, Taşbaşı kasabaya götüren askerlerden Cumali Onbaşının Alevi olduğunu dile getirirken, aslında biraz da romanlarındaki bireylere yön veren kültürel özü dışa vurur: "Yeryüzüne insan yaratı̆̆ gibi değerli hiçbir yaratık gelmemişti. Allah bile insan suretinde tecelli ederdi. Allahtan sonra, belki de ondan önce yerin gögü̈n yaratıcısı insandl. Allah bir ışık olarak görünürdü. Ve o 1şı1k tekmil insanlarda vard1. Belki bir gün iyilerin iyisi bir insanda gözükürdü. $\mathrm{O}$ yüzdendir ki Aleviler insana ve 1şığa secde ederlerdi” (Kemal, 2000h, s. 342).

Kemal genelde iyilik ve kötülük içerikli bir söylem geliştirir. Yoksulluk, zulüm, ayrılık, aşağılanma karşısında bir kardeşlik özlemini canlı tutar. Ayrıca üç ciltlik roman boyunca insanın ölüm karşısındaki arayışını, varoluşsal kaygılarını ve bu dünyada gelip geçiciliğin bilincinde olmanın tartışmalarını sık sık okuruz. Örneğin ölüm karşısında çaresiz kalışını kanıksayan Koca Halil, “ölümün olmadı̆̆l, ölümün ulaşamayacă̆ bir yer arıyorum” (Kemal, 2000i, s. 22) demekten de kendisini alamaz. Romanın sonlarına doğru Muhtar Sefer pamukta, Meryemce'yi yaşıı olması nedeniyle köyde bırakan oğlu Ali'den, hasmı olan Taşbaş’ın arkadaşı olduğu için öç almanın yollarını aramaktadır. Ali’nin kendi annesini öldürdüğü yalanını dillendirir. Önceden bir adamını köye gönderip Ali’nin annesini öldürtür. Yazar, Sefer'in iç planlarından birinde araya girer, bir insanın canını ortadan kaldırabilmenin evrensel arşivinde yer etmiş yönüne dikkat çeker: “...Bugünkü dünya topră̆ kötü insanların ektiği acıların, alçaklığın, aşağılı̆̆ın bitmesine, gelişmesine elverişli topraktır.” Köyde bir başına kalan Meryemce ise insanla başlayıp biten bir dünyanın hâlini özetler: "...Demek dünyayı dolduran insanmış. Her şey, her şey, bütün dünya insanmış. Insan yoksa dünya yokmuş.” $\mathrm{Bu}$ arada Kel Aşığı anımsar: “...Dünyaya gelmiş hiçbir yaratık insan kadar birbirine, ve de dünyadaki öteki yaratıklara kötülük düşünemez ve de iyilik...” (Kemal, 2000i, s. 137, 262).

Yaşar Kemal'in otobiyografisi niteliğindeki Kimsecik üçlüsünde, insanın türlü hâllerine ilişkin arayışı roman karakterleri aracılığıyla sürer. İsmail Ağa, Hasan'la alın terinin değeri üzerine düşüncelerini paylaşır: "Nerede alnın terlerse orada güzellik var” (Kemal, 1998a, s. 114). İnsanın emeğiyle, dünyada bir boşluğa düşmeden kendisini oluşturarak var olma mücadelesi özetlenirken, sevgi üzerine söylenenlerde insan değeri göz önünde tutulur: Dal Emine’nin İsmail Ağa’ya karşılıksız sevgisi konuşulduğunda Hasan söyler, “Dünyada her şeyi yapacaksın, kadınların sevdasını küçük düşürmeyeceksin” (Kemal, 1999a, s. 18). Ve Mustafa'nın iyileşmesinde yardımcı olan Emine'ye Zero sevginin bir başka boyutunu dile 
getirir: “...sevip de sevildiğini bilmemek, bir kadın için ölümden de bin beter olurdu” (Kemal, 1999b, s. 494). Bir bakarsınız yazar, dünyanın birçok hali karşısında, İsmail Ağa gibi gözleri “her zaman, her şeye acımayla bakar,” bir bakarsınız ceviz ağacını budayan Topal Hacı'yla karşımıza çıkar: “...çok gizler var insanda akıl erdiremediğimiz... ăgaç da insan gibidir, içi, budakları giz doludur” (Kemal, 1999a, s. 29, 101).

Babası gözlerinin önünde öldürüldükten sonra konuşamayan Mustafa'yı, annesi Zero, Doktor Ahmet Beye götürür. Doktor çocuğun korktuğunu söyler: “...Hepimiz, bütün insanlar çılgıncasına korkuyu yaşıyoruz. Her an, her saniye, her şeyden korkuyoruz. İnsanoğlunun mayası korkuyla yuğrulmuş... korkudur insanı bir yerlere götüren" (Kemal, 1999a, s. 113). Korku bu romanda da yerini almıştır. Kültürel bir ritüel olan Hıdrellez şenliklerinde “... bu dünyada her şey alışkanlıktır” denmesine rağmen korkuya alış1lamıyor ki Eşkıya Sefer, "korku insanoğlunun başına en büyük beladır" çıkarsamasında bulunur. Korku evreninde gezinen Mustafa aracılığıyla yazar çok önemli bir mesaj verir: "erkeklerin kadınları öldürmesi onursuzluk”tur. Bu onursuzluğa düşmeden her telaş “dünyayı çoğaltmak, dünyayı hak etmek" üzerinedir. Romanda beşeri dünyanın insanların gözündeki algılanışıyla ilgili varoluşsal bilgileri Ali Çavuş, Zero'ya anlatır: “...Şu toprakta, şu denizde, şu gökte, şu yıldızlarda ne kadar çok yaratık varsa, o kadar da çok akıl var. O kadar çok içgüdü. Şu toprakta, şu suda, şu gökte en az koku alan, en az toprağa uyan, soğukta en çok üşüyen, sicakta en çok yanan, en çok yoksulluk çeken biziz... Öteki yaratıklar aç kalırlarsa... Hayvan aç kalınca ölür. Ölümün olduğu gibi, yoksulluğun da şu dünyada acısını duyan biziz.” Çok sevdiği kuşun gidişinden sonra köpeği yiten Mustafa’ya söyletir: “...Dostluklar boşlanmaya gelmez. Bir gün öyle, bir gün böyle yok. Dostluklar sonuna kadardır. ...Yaşayan her yaratık, ekmek, su, uyku kadar bir şeye daha gerek duyar, o da sevgiye... Şu yaratıklar içinde ölümün ne olduğunu bilen tek yaratık insandır. Onun için, bu yüzden insanlar böylesine çılgın, böylesine deliler. Ölüm korkusu, ölüm acısı, yok olma onları delirtip, onlara olmadık işler yaptırıyor. Ölüme aldırmaz görünüyorlar ya insanların gece gündüz düşündükleri, hiç akıllarından çıkarmadıkları ölümdür. Öteki yaratıklar ölümü bilmedikleri için daha az zalimdirler... Öteki yaratıklar ölümü bilmedikleri için insandan daha çok sevgi doludurlar” (Kemal, 1999b, s. 256, 314, 344, 347, 398, 429).

Yazar, yoldan geçen bir çoban olur, Köroğlu'na ders verir, “...Şu evren içinde ne kadar yaratık varsa en kutsalı insandır. Hiçbir insanı küçük göremezsin, aşă̆ılatamazsın. İnsanı aşağılatan önce kendisini aşağılatmış demektir. Kendine saygısı olan, olumlu, sağlıklı bir adam başkalarına da en büyük saygıyı duyar" (Kemal, 2001b, s. 59). Özetle bir okuyucu olarak kendimizi, Kimsecik üçlüsünde ölüm, korku, insan sevgisi, insan hayvan dostluğu ve kadına verilen değer üzerine feodal bir toplumda pek de alışkın olmadığımız önemde tartışmaların ortasinda buluruz.

Kimsecik'te kadın öldürmenin onursuz bir davranış olduğunu yazar Mustafa'ya söyletirken, Yılanı Öldürseler'de büyükananın marifetiyle, "kadınları çocuklara öldürtürler” (Kemal, 2001a, s. 67). Büyükana psikolojik baskısıyla torunu Hasan’a, gelini Esme’yi öldürtür. Burada yaşı bir kadının, torununa gelinini öldürtecek hale gelmesinde yalnızca patolojik davranışlarını değil, kolaylıkla suçlanan bir gelinin ataerkil toplumda nasıl bir başına bırakıldığını da görürüz. 
Yaşar Kemal'in Binboğalar Efsanesi, her ne kadar toprağa yerleşmekte direnince savrulan bir Yörük obasının başına gelen olumsuzluklar karşısında giderek yitişini genel hatlarıyla verse de aslında değişimin götürdükleri Yörüklerle özdeş insancıl öz barındıran kadim bir kültürün, bir kuşak sonra belki de yok oluşunun gerçek anlatısıdır. Yazar okuyucuyu bu trajedinin içine sürüklerken iyi olanın yanında nasıl yer alınır tartışmasına da sürüklemektedir. İnsan ve yaşam üzerine varoluşsal kaygıların yatırıldığı felsefi arayış bu romanda çok yönlü olarak işlenir. Örneğin bir Hıdrellez gününde dilek tutmak için herkes nehre, yıldızlara bakar, Müslüm ise ölümsüz olmayı ister, ancak “dünyada ölen bir tek yaratık vardır: Dünyada ölümlü bir tek canlı vardır, o da insandır, o da insandır, insandır.” $\mathrm{O}$ da yaşam çiçeği ister, “...Ben öldükten sonra dünyayı ölümün çaresi olan çiçeğe boğmuşsun ne fayda! Ben gittikten sonra bir daha gelmem ki...” (Kemal, 2001c, s. 29, 268). Yine zamanı geldiğinde beş mayısı altı mayısa bağlayan gece, Hıdrellez hazırlığı yapılır, Koyun Dede, Dost Dede, Sümbül Dede gelir, Genç Ali Dede gelirken üç kere Hızır'la karşılaşır. Bu karşılaşmada dilek söylemeye ilişkin vurguladığı şu cümle her şeyin insanda başlayıp bittiğini özetleyen materyalist bir anlayış barındırır içinde: "yürü git yoluna ya Hızır, benim senden hiçbir dileğim yok, ben insanım, kendi dileğimi kendim yerine getiririm...” (Kemal, 2001c, s. 266). Yörük obasını kurtaracak kılıcı yapmaya çalışan demirci piri Haydar Usta obanın bir sona gittiğini bilse dahi umudun nasıl gerekli yaşamsal bir duygu olduğunu söylemekten geri durmaz: "Bakın kardaşlar, bakın yiğitlerim. Umutsuz olmayın, umutsuzluk kötüdür, beladır. Umutsuzluk diri, canl,, soluk alan insana yakışmaz. Umutsuzluk ancak ölülere mahsustur...” (Kemal, 2001c, s. 37).

Yaşar Kemal, insan felsefesinin varoluşsal kaynaklarının başında gelen, insana dair bireysel deneyimlerden süzülen düşüncelerin yanı sıra insancıl bir kültürden gelen değerlerle roman kimliğini oluşturur. Mutlak sonun olmadığı bir evrende doğayla bütünleşmiş, umuttan ve sevgiden vazgeçmemeyi içselleştirmiş roman karakterlerini bu bütünlük çerçevesinde kurgular. Böylece hümanizmi romanın psikolojik dokusunda da var kılar.

Yaşar Kemal, bu dünyayı ele alan seküler bir romancı olmanın yanında insan maneviyatının türlü hâllerini işleyen güçlü bir yazardır. Onun roman malzemesinin ana kaynağını oluşturan, bu dünyadaki insanın varlığıdır. Bu nedenle insanı ekosistem içinde verir. Farklı yaş grubundan insanların içsel yaşamını paylaşır. Sonuçta kendisiyle başlayıp yaşayan bir evrenin bilincinde bir hayat sürdüren roman karakterleri işlevsellik bulur.

Bir çocuğun merkezde olduğu Al Gözüm Seyreyle Salih romanında ise 1970'li yılların Türkiye'sinde Karadeniz kıyısında bir yerleşimde çocuk roman kahramanı Salih'in çevresini, ailesini, yaralı bir martıyla dostluğunu okurken onun gözünden insan, doğa ve çevre sorunsalına eğiliriz. Bez dokuyan ailelerin, balıkçıların, Metin gibi kaçakçıların, Hacı Nusret gibi tefecilerin, İsmail Usta gibi demircilerin, şiddet gören kadınların yaşadığı bir kasabada Salih, evrensel insan özünü bize vermektedir. Örneğin Salih deniz yüzeyinde ölü bir kuşu izler. Sonra düşünür: "Ölüm neydi, ölüm neredeydi? Nasıl bir şeydi? Şu denizde durmadan oynayan, batıp çıkan kuş, nasıl böyle ölmüştü? Ölüm neydi, nereden geliyordu, var olan bir şey miydi? ” Öte yandan “hep bir çoğalan mutlulukta, bir umutta gülümseyen” bir karakter özelliğine sahiptir. Çünkü o çocuktur. Yazarın kendi çocukluğuna benzer: "Salih büyülüydü, dünyaya çalınmıştı. Neyi, nerede görse şaşırıveriyordu bu büyü karşısında...” Boncuklu arıları romanda saatlerce inceler, ona göre “arllar hep bahar gibi kokarlar.” Ölüm olgusu 
bazen başköşeye oturur. Denizde kaçakçılık yapan Metin’i anlatırken yazar, “ölüm korkusu insanlart iyi insan yapar" değerlendirmesinde bulunur (Kemal, 2000g, s. 8, 38, 50, 72, 114). Halk söylencelerinin, masallarının kullanıldığı romanda, yaralı martısını iyileştirmek için uğraşı veren Salih'le, ölümün otu üzerine konuşan Yılan Şehzade, okuyucuyu “...Insandan başka hiçbir yaratık ölümsüzlük istemez” mottosuna sürükler. Yeri gelir, "bahar kokusu yüreğinden tüm karanlıkları söküp alıp götürüyor”, “içinde hep o yitirdiğini arama, bulma duygusu." Evet Salih için, “macera bir ömür pahasına varllacak diyardı. Hiç kimsenin de varamadığı bir yerdi. ” Salih'in dünyası renklidir, bir bakarsınız düşlerindeki masalların içinden Korsanlar Padişahı çıkagelir, bir bakarsınız Halil İbrahim Peygamber... Ve yazar Halil İbrahim Peygambere söz verdirmeyi unutmaz: “...bu çocuğun yüzü suyu hürmetine dünya bolluktan dolup taşacak. Kimse kimseyi, kimse hiçbir yaratı̆̆ aşağllayamayacak. Insanoğlu, tekmil yaratıklar zulmü unutacaklar. Bir şikayet olursa o da ölümden olacak..." (Kemal, 2000g, s. 104, 107, 120, 134, 306). Salih, demirci İsmail Ustanın da yakınındadır. Demir döverken çıkan sesi kadim bir çalgı olarak görür, demircilerin türküsünden yola çıkarken, bu sesleri dinleyen en kötü insanların bile iyileşeceğini söyler: “...Bu insanlar artık bir süre için karllarını dövemeyecek, çocuklarına zulmedemeyecek, komşularına kötü bakmayacak, kazık atamayacak, düşmanlık edemeyecek, mutlu olacaklardır, ta ki Ísmail Ustayl, çekicini, kıvılcımlarını, sesini unutuncaya kadar” (Kemal, 2000g, s. 147).

Görülüyor ki, Yaşar Kemal'de insanların birlikte onurlarıyla mutlu yaşayacağı, eşit olacaklarına dair eşitlik, özgürlük söylemi, insanların şiddet görmeyeceği bir dünya özlemi vardır. Buna benzer bir durum başka bir örnekte de görülür: Salih'in babası çalışmaz, ev halkının bez dokuyarak edindiği parayı tüketir, kumar oynar, alkol alır, eşine şiddet uygulardı. Bir gün kendisiyle yüzleşerek eve gelir, yazar bu roman karakterini bir anda baştan sona aydınlatmıştır sanki, baba ev halkına uzun bir söylev çeker: “... ben ben, ben ben insan olmanın kadrini kıymetini bilmedim. Insan olmak, aaah, insan olmak, çalışmak, üretmek, demektir... Çallşacă̆ım, kimseyi, sizi sömürmeyeceğim ... en büyük insanlık sömürüye başkaldırmaktır...” (Kemal, 2000g, s. 167). Verilen mesaj insanın insanı sömürmesinin nasıl aşağılık bir davranış olduğu gerçeğidir. Romanda yazar doğa sevgisinin insana kattığg güzelliği de işler. Salih martısını kokladığında, “yeyni bahar denizi kokusu”nu alırdı içine. Bu koku ona göre bir sevgi, umut, güzel bir yanla doldururdu insanı. Ilık bahar denizinin kokusu gibi. Ilık bahar denizi kokusu geldiğinde öyle ki, “...Işste böyle zamanlarda deniz, kum, kayalar, balıklar, çiçekler, insanlar, kokular, ne varsa dünyada çirkin, güzel bin misli güzelleşir, insan doğan güne karışır, bir yeniden doğmanın, insan gibi insan olmanın, insanlıkta terütaze olmanın, yeniden, bilerek yeniden doğmanın bilincinde olmanın, dünyayla birlikte yaratılmanın sevincine varır, bir dalgaya düşer, kendinden kopar, büyük doğanın sevincine varır, özünde insan olmanın, o erişilmez sevincine varır. İnsanoğlu bu sevinci her zaman tadabilir. Insanların çocuklukta böyle sevinçleri sık sık tatmaları boşuna değildir. Çocuklar doğanın yaratılma, doğurma, yaratma sevincine katılabilirler, yakınlıklarından, kopmamışlıklarından...” (Kemal, 2000g, s. 248). Yaşar Kemal'de doğaya duyulan bağlılık, özellikle çocuk hayvan dostluğu ilişkisinden verilen, yaşayan canlılara dostça davranmak anlayışı insancıl bir felsefeyle ancak çözümlenebilir. Doktor Yasef, Anadolu'da yaşanan savaşlardan söz ederken, Salih'e arada şunu söyler, "bir tek insan, şahıslar da kendilerini, geçen günlerini bir daha yaşayamazlar..." 
(Kemal, 2000g, s. 278). İşte doğanın dönüşümünü buna ortak eder. Aynı doğa değildir, bir sonraki yıla kalan... Değişen bir doğada, toplumda, yaşanan kötülüklerin yaygın olmasına rağmen insanın daha güçlü ve iyi bir geçmişin birikimine sahip çıktığında yaşamının kolaylaşabileceğini, mutlu olmanın uzak olmadığını okuyucunun belleğine yerleştirir.

Yaşar Kemal, insanı çevresi içinde bir bütün olarak değerlendirir. İnsanın yaşadığı çevrenin yaşanır olmasını insanın becerisiyle ilişkili tutar. İnsan belki de istemediği halde kötü olanın yanında durabilmekte; dünyayı daha çekilmez hale getirebilmekteydi. Kemal'in Deniz Küstü romanının daha başlangıcında, insanların birbirlerine kötülük yaptıklarını gördüklerinde özellikle balıkçı Selim'e yapılanlardan sonra yaşananları üst anlatıcı şöyle dile getirir: "Oysaki bu dünya böyle, bu insanlar böyle. Benim elimden ne gelir ki... diyemiyorum, içim götürmüyor, bir yerlerimden bir kire, iyi olmayan, dostça olmayan bir şeye bulaşmış gibi oluyorum. İçim kararıyor, içimin karanlığını delemiyor, uzun bir süre içimi arındıramıyorum." Romanın geçtiği Menekşe'de olmasını düşlediği adayı da paylaşır: "Bir de adamdaki her insanın evine girip çıkmall, her evi evim, her insanı kardeşten de ileri gönül, kafa, yürek yoldaşım yapmalı, her işlerine koşmalı, en küçük dertlerini derdim bilmeliydim. " İşte bu ada uzun yıllar sonra yazarın kaleme alacağı Bir Ada Hikâyesi roman serisinin mekânı, Karınca Adası olacak, Poyraz Musa karakteri ise düşlediklerini hayata geçirmiş olacaktır. Yazarın umuda yorduğumuz şu ifadesi umudun aydınlığını niteler: "Adamda çok işler, çok güzel şeyler oldu... Düş kurdular insanlar durmadan... Düş kurmaktan utanmadılar. Bir gün bu düşler gerçekleşemez, demeden, umutlarını içlerine gömme belasına uğramadan...” (Kemal, 1998b, s. 23, 24).

Yaşar Kemal, romanı yazan ve yaşayandır. Roman karakterleriyle iletişiminin yanında kendi içsel dünyasında varoluşsal bir arayıcıdır, Mahmut ile konuştukları bir sırada içinden de şöyle konuşur: "Insanlar bu kadar korkmasalar, bu kadar zalim olurlar mı, bu kadar birbirlerine düşmanlık eder, birbirlerinin böylesine kuyularını kazarlar mı, insan öldürürler mi, birbirlerine böylesine kıyar, köle eder sömürürler mi, birbirlerinin sırtına binerler mi, aşağllarlar mı, delirirler mi, sevmeyi, sevişmeyi böylesine unuturlar mı, uzattıkları el böylesine buz gibi olur mu, düşünebilme yeteneklerini böylesine yitirirler mi, öykünürler mi, durmadan ölümü düşünürler mi, ölümü düşünmenin boşluğunun farkına varmazlar mı, bastıkları yeri görmeyecek kadar üstümüzdeki gökten, altımızdaki topraktan, yıldızlardan, sulardan, çiçeklerden, dă̆ başlarından, ışıktan böylesine bihaber kalırlar mi, sevgisiz, sevişiz, dostluksuz yürekleri sıcacık, bir sevgili, bir dost yüzü için, bir kuş gibi çırpınarak çırpmadan olur mu?" (Kemal, 1998b, s. 26, 27). Yazar, insanla ilgili dertlenişini her dem sürdür. Bir insani özlemde insanların yaşadıklarını kritik eder. Yunuslarla dostluk kuran balıkçı Selim'in penceresinden aktarır: “...Umutsuz olan, nankör olan insandır. Dünyanın güzelliğini yadsıyan artık salt yaşamanın tadına varamayan insandır, altında yaşadığg göğ̈̈u, üstünde gezdiği topră̆l, akan suları göremeyen insandır. Görkemli doğa ortasında görmeden dolaşan, bakarkör olan insandır..." Ve balıkçı Selim dile getirir: "Hayvan olmak bu çağda insan olmaktan daha mutluluktur” (Kemal, 1998b, s. 35). Yazar yozlaşan bir dünyanın sinir uçlarında gezinirken, tüm eksikliklere rağmen balıkçı Selim ile denize açıldığı günlerde doğanın güzelliğini sunar: "ben oltamı toplarken gün battı, ortalık inanılmaz güzellikte kadife yumuşaklığında, tiril tiril, görülmemiş ışıll bir maviye kesti. Gök, deniz, hava bu kadife mavisinde bütünleşti, deniz koktu” (Kemal, 1998b, s. 41). Balıkçı Selim, insanların dedikodularına maruz kaldığında, 
dürüst olmayan tutumlarıyla karşılaştığında kendine kapandığı olur, hele dostluk kurduğu yunus balığı ortadan kaybolduğunda, deniz küstüğünde ve Marmara'da yunuslar yağları için öldürüldüğünde bir başkalaşır: “...Niçin bu kadar öldürmeyi, yok etmeyi, parçalamayı seviyor insanlar? Insan yumuşak başlı, iyilik dolu bir yaratıktır, ă̆ız dolusu gülen, yürek dolusu ağlayan, iliklerine kadar duygulanan, seven bir yaratıktır insanoğlu... Bu öldürme, yok etme, öfke, öç, sevgisizlik neden? Niçin kopartyorlar çiçekleri, birisi tok da yüz bini niçin aç, o tok da bu kadar gözün altında, öfkenin içinde iflah oluyor mu? Tok olan niye bu kadar ahmak?” (Kemal, 1998b, s. 46). Balıkçıların hakkını yerken genç yaşta ölen Laz Mazhar Bey’i anlatırken beşeri bir hesaplaşmaya önem atfeder: "İnsanın hakkı er geç, ama erinde geçinde boğazına çakılır kalır yiyenin. "Yazar doğaya zarar vereni de bu hesaplaşmada bir yere koyar: "birbirlerinin gözlerini oyanların ..., çaresizleri ezenlerin ... fikaraların derisini yüzenlerin..., deniz kurutanların...” yaşandığı yılları ele alırken (Kemal, 1998b, s. 73, 94), denizi kirletenleri... ögürtücü bir kokuyla kokan Haliç’i yaşanmaz haline getirenleri yüzleşmeye çağırır.

Yazarın İstanbul'da geçen bir başka romanı ise Kuşlar da Gitti'dir. Yaşar Kemal, binlerce kuşun çıkageldiği Florya düzlüğünden hareket ederek İstanbul'un tarihini yazanların, Florya'nın kuşlarını da yazmaları gerektiğini söyler. Ötede İstanbul değişmektedir. Kurulan gecekondularıyla, insanlar arasındaki hırs, kavga ve sosyal kötülüklerle... Eskiden kuş alıp azat eden insanlar çok azalmıştır: "Günler geçtikçe dikenlik küçüldü, Şenlikköy, Yeşilköy, Ambarl, Cennet Mahallesi, Telsizler, Menekşe. Florya, Basınköy kuruldu. Floryanın o güzelim menekşe dolu koyağına çirkinin çirkini beton apartmanlar yı̆̆dılar. İste kuşlara bu küçücükyer kald, denizle orman, Menekşeyle Basınköy arası... Ve kuşlar her yıl gelip bu küçücük dikenliğe siğınıyorlar. Geçen yıl bu dikenliğin sahibi de burasını, parselledi, metrekaresini üç yüz, beş yüz liradan okuttu yeni zenginlere..." (Kemal, 2000f, s. 53). Bir yandan da Anadolu'dan göç yoğunlaşmıştır. Gecekondulaşma alıp başını gitmiştir. Yazar İstanbul'u, çoğaldıkça, betonlaştıkça, insanlığını unutmuş, yitmiş olarak değerlendirirken, romanın içinde çocuklarla beraberdir. Örneğin bir yerde Mahmut'la konuşurken dile getirdiği, "umutların öldüğüne iyice inandığın bir anda insanlık, bin bir yönden açan bir ışı-umut çiçeğiyle birden aydınlanıverir” (Kemal, 2000f, s. 52) cümlesi insanlık ailesine bıraktığı en güzel miraslardan birisidir. Biliyoruz ki, Yaşar Kemal kötünün yanında değildir. Doğayı yaşanmaz hale getiren insanları eleştirirken, halkın gücüne olan inancını kimi romanlarında açıkça roman karakterleri yolu ile iletir. Örneğin A $\breve{g r l d a g ̆ l ~ E f s a n e s i ~ y a p ı t ı n d a ~ M a h m u t ~ H a n ~ h a l k ı n ~ y u ̈ k s e l e n ~ t e p k i s i n d e n ~ k o k t u g ̆ u ~}$ için kızı Gülbahar'a âşık Kavalcı Ahmet'i bağışlar. Mahmut Han'ın geri adım atmasından sonra, kalabalıktan Demirci Hüso, insanlar arası dayanışmanın öneminin altını çizer: "Biz hep böyle, her şeyde birlik olsak, kimse bize diş geçiremez. Bize dağlar, şahlar dayanamaz. Hiç kimse... Yeter ki böyle birlik olalım” (Kemal, 2000e, s. 107). Teneke'de ise üst anlatıcı rolüyle Kemal, çeltik ağalarının yaşanmaz hale getirdiği köylerde, yoksul köylülerin birlikteliğini ve haklı davalarını verirken, köylülerin yanında yer alan arzuhalci komünist Kör Cemal olur. Bu romanda, ağaların kurşunlattığı arzuhalci komünist Kör Cemal karakteriyle karşımıza çıkar.

Kısaca Yaşar Kemal'in roman diyalektiği, insan onuruna ve haysiyetine gösterilen sayg1nın, insana duyulan sevginin ve güvenin felsefi temelleriyle beslenirken, Çukurova Türkmen kültürünün insana, doğaya ve yaşayan her canlıya yaklaşımını, kimliğinde bir varlık alanı olarak inşa etmiştir. 


\section{Sonuç}

Yaşar Kemal'in çocukluğu ve ilk gençlik yılları adaletsizliğin hüküm sürdüğü, eşkıyaların ve ağaların sarmaladığı bir kırsal toplumsal yapıda, insanı değer gözeten bir kültürün en doruk noktasıyla insanın bir değerinin olmadığı, katillerin cezalandırılmadığı, köylülerin yoksul olduğu, insanların şiddet gördüğü bir ortamda geçmiştir. Yaşar Kemal'in yetiştiği sosyal çevre ve çocukluk döneminde yaşadıkları edebiyatının biçimlenmesinde etkili olmuştur. Psiko-sosyal açıdan Yaşar Kemal, güçlü bilişsel, duygusal donanımı ile kendisini çocukluğunun, bilinçdışının zengin ve evrensel nitelikteki derinliklerine bırakabilmekte, psikanalizde benliğin hizmetinde gerileme diye bilinen bir süreci sıklıkla, rahatlıkla kullanabilmektedir. Benliğin hizmetinde gerileme, sanatçının geçici sürelerle, denetimli biçimde çocukluk çağına, bilinçdışına inebilmesi, bilinçdışının zengin içeriğini bilince taşıması, kazandırması olarak anlam bulmuştur (Öztürk, 2016, s. 186). Öte yandan Yaşar Kemal'in roman türündeki yaratıcılığı insan ve toplum gerçeğine ilişkin egzistansiyalist bir arayıştır. Yozlaşan, çürüyen bir toplumda doğru sözlü bir şekilde çürümeyi yansıtırken toplumsal görevinden de kaçmaz. Öyle ki, sanatın dünyanın değişebileceğini göstermesi ve değişmesine yardım edebilmesi Yaşar Kemal'de karşılığını bulmaktadır (Fischer, 1993, s. 45). Bu değişimin farklı boyutlarında Yaşar Kemal, insana duyduğu güveni ve umudu asla geri plana itmemiştir. Bunda hem sanatsal bilinci hem de yaşam tarzı etkili olmuştur. Örneğin daha ilk gençlik dönemlerinde bile “...ben on yedi yaşımdan beri Türkiye'deki emekçilerin yanındayım... Türkiye’nin bağımsızlığının, yüzde yüz bağımsızlığının yanında” olduğunu söylerken, çocukluk çağının psikolojik derinlikleriyle yaşadığı toplumun gerçekliklerini yaratıcı bir şekilde harmanlayabilmiştir. Yazar doğal olarak romanlarında bu paradigmaya sadık bir anlayışı ortaya çıkarmıştır. Bunu her an tutkuların bütün ağırlığıyla, yüzeyden en derinlere ve derinlerden yüzeye doğru geçmek mecburiyetinde kalarak yaparken, yaşamın kendisinin de bundan başka bir şey olmadığını yer yer gösterebilmiştir (Nichanian, 2011, s. 242).

Toplumsal yapının birçok ögesine bağlı olarak toplumsal koşullar değişirken, insanlar da bu değişime uyum sağlamaya çalışır. İnsan ve toplum yaşamı etkileşim halinde süregider. İnsanın çocukluk çağı, bilinç dışının zengin içeriğinin elbette kültürlendiği bir sosyal çevre vardır. Bu anlamda Tharaud'a göre, Yaşar Kemal bir Alevi köyünde büyümüştür ve onun idealizmi ile hümanizmi, örneğin Yer Demir Gök Bakır'da ifade edilen Alevi değerlerini yansıtıyor görünmektedir. Onun yazıları, acı çeken insanlığın en acı ve en dayanılmaz durumlarını yansıtırken bile, ışı̆̆ı, umudu ve insan sevgisini ifade eder (Tharaud, 2017, s. 448). Aynı şekilde Bir Ada Hikâyesi'nde Melek Hatun ile Girit Mübadili Musa Kazım Efendi'nin yaşama bakış açılarında, insanlarla ilişkilerinde, sevgiyi ve insana saygıyı benimsemelerinde de bunu görürüz. Binboğalar Efsanesi'nde ise insana, doğaya, kadına ve kültüre saygının temsili olan Türkmen kültürünün toprağa yerleşme ve endüstriyel tarıma geçişte, sermaye ile tanıştıktan sonra darda kalmış bu son Türkmen aşiretine karşı yeni ağaların, bürokrasinin acımasız yaklaşımıyla birlikte değerlendirildiğinde değişen maddi koşulların, insan ve toplum gerçekliğini anlamımızda ne kadar güçlü bir veri olduğunu bize gösterir. Elbette olumlu-olumsuz birçok unsuru yazar işlerken, Haydar Usta'da somutluk bulan, sevgi, insana saygı, umut ve insandan en güzel şeylerin beklenmesine olan inanç bu kültürün değerlerini göstermeye yeter. Bu nedenle roman tam da gerçek dünya temsiliyle fevkalade iç içe geçtiği için, sadece be- 
timlediğini iddia ettiği dünyayı şekillendirmek üzere çok şey yapabilir (Mackay, 2018, s. 35). Işı̆̆ı̆ destancısı Yaşar Kemal'in insan sevgisini ve sıcaklığını yüreklerinde taşıyan karakterleri, fail olarak toplumun yeniden insancıl kurgusunda bu anlamda müdahil olabilmektedirler. Ayrıca felsefi temellere dayandırdığ 1 Anadolu Türkmen kültürünün bir mirasçısı olmayı seçtiği kadar kendisi de evrensel bir yazardır. Her şeyden önce insan hak ve özgürlüklerini savunmak konusunda entelektüel bir duruşa ve onura sahiptir. Yaşadığ coğrafyanın insanının ve dünya halklarının refah ve demokrasi nimetinden yararlanmasını savunur. Ülkesinin gerçeklerine yabancı olmayan bir demokrattır. Demokrasiyi tehlikeye atarak dünyayla aramıza duvarlar örüp sadece kendi meselelerimizle ilgilenerek, evimizdeki hürriyetlerimizi etkin bir şekilde koruyamaya çalışanların (Bauman, 2014, s. 31) yanında olmadığı gibi dünyadaki tüm insanların demokrasiden, insan hak ve özgürlüklerinden ve sosyal adaletten pay almasının mücadelesini yapmış, yaşamının her döneminde yazdığı her cümlede tereddüt etmeden bu mücadelenin gereklerini yerine getirmiştir. Açıkçası romanlarının varoluşsal kaynakları bu değerlerden de beslenmiştir.

\section{Kaynaklar}

Bauman, Z. (2014). Modernite, kapitalizm, sosyalizm. (F. D. Ergun, Çev.). (2.Baskı) İstanbul: Say. Bauman, Z. (2017a). Hermenötik ve sosyal bilimler, (H. Oruç, Çev.), İstanbul: Ayrıntı.

Bauman, Z. (2017b). Kimlik. (M. Hazır, Çev.). Ankara: Heretik.

Bataille, G. (2016). Edebiyat ve kötülük. (A. Sönmezay, Çev.). (4. Baskı). İstanbul: Ayrıntı.

Fischer, E. (1993). Sanatın gerekliliği. (C. Çapan, Çev.). (7.Baskı). Ankara: Verso.

Kemal, Y. (2000a). Ince Memed 1. (8.Baskl). İstanbul: Adam.

Kemal, Y. (2000b). Ince Memed 2. (6.Baskı). İstanbul: Adam.

Kemal, Y. (2000c). Ince Memed 3. (6.Baskl). İstanbul: Adam.

Kemal, Y. (2000d). Ince Memed 4. (6.Baskı). İstanbul: Adam.

Kemal, Y. (2000e). A ̈̆rldă̆ efsanesi. (8.Baskl). İstanbul: Adam.

Kemal, Y.(2000f). Kuşlar da gitti. (5.Baskl). İstanbul: Adam.

Kemal, Y. (2000g). Al gözüm seyreyle salih. (4.Baskı). İstanbul: Adam.

Kemal, Y. (2000̆̆). Ortadirek/Dağın öte yüzü 1. (5.Baskl). İstanbul: Adam.

Kemal, Y. (2000h). Yer demir gök bakır/Dağın öte yüzü 2. (7.Baskı). İstanbul: Adam.

Kemal, Y. (2000i). Ölmez otu/Dă̆ın öte yüzü 3. (5.Baskl). İstanbul: Adam.

Kemal, Y. (1998a). Yağmurcuk kuşu/Kimsecik 1. (3.Baskı). İstanbul: Adam.

Kemal, Y. (1998b). Deniz küstü. (3.Baskı). İstanbul: Adam.

Kemal, Y. (1998c). Demirciler çarşısı cinayeti/Akçasazın ağaları 1. (3.Baskı). İstanbul: Adam.

Kemal, Y. (1999a). Kale kapisi/Kimsecik 2. (3.Baskl). İstanbul: Adam.

Kemal, Y. (1999b). Kanın sesi/Kimsecik 3. (3.Baskl). İstanbul: Adam.

Kemal, Y. (1999c). Yusufçuk Yusuf/Akçasazın ağaları 2. (3.Baskı). İstanbul: Adam.

Kemal, Y. (2001a). Yılanı öldürseler. (8.Baskı). İstanbul: Adam.

Kemal, Y. (2001b). Üç Anadolu efsanesi. (8.Baskl). İstanbul: Adam.

Kemal, Y. (2001c). Binboğalar efsanesi. (5.Baski). İstanbul: Adam.

Mackay, M. (2018). Roman nedir? (F. Akdoğan Özdemir, Çev.). İstanbul: Boğaziçi.

Mengüşoğlu, T. (2017). İnsan felsefesi. (2.Baskl). İstanbul: Doğu Bat1. 
Nichanian, M. (2011). Edebiyat ve felaket. (A. Sönmezay, Çev.). İstanbul: İletişim.

Öztürk, O, M. (2016). Özerk benlik, kul benlik. (3.Baskl). İstanbul: Okuyan Us.

Sadak, Y. (2017). Yaşar Kemal ya da Dionysos'un dönüşü. İstanbul: Öteki.

Tharaud, C. B. (2017). Çukurova Yaşar Kemal edebiyatının temelleri. (T. Çulhaoğlu, Çev.). İstanbul: Yap1 Kredi. 